\title{
Drug design: 4-thiazolidinones applications. Part 2. Pharmacological profiles
}

\author{
Roman Lesyk \\ Danylo Halytsky Lviv National Medical University, Ukraine \\ (iD) https://orcid.org/0000-0002-3322-0080 \\ Corresponding author: dr_r_lesyk@org.lviv.net
}

DOI: https://doi.org/10.20883/medical.e407

Keywords: Structure-based drug design, 5-Ene-4-thiazolidinones, Thiopyrano[2,3-d]thiazoles, biological activity, SAR analysis, Michael acceptors
Published: 2020-06-26

How to cite: Lesyk R. Drug design: 4-thiazolidinones applications. Part 2. Pharmacological profiles. JMS [Internet]. 2020 Jun 26;89(2):e407. doi:10.20883/medical.e407

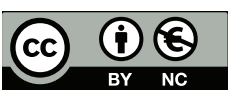

(C) 2020 by the author(s). This is an open access article distributed under the terms and conditions of the Creative Commons Attribution (CC BY-NC) licencse. Published by Poznan University of Medical Sciences

\begin{abstract}
Following the chemical diversity of 4-thiazolidinones, an in-house library of new heterocycles was designed and synthesised (more 7000 compounds). Anticancer, antitrypanosomal, antituberculosis and antiviral activity screening led to the SAR database formation, lead-compound identification, design of focussed sub-libraries, as well as the formation and validation of hypotheses for structure optimisation: i) complications of $\mathrm{C} 5$ fragment and/or functionalisation of N3 position; ii) creation of the hybrid molecules; iii) fixation of 5-ene-4-thiazolidinones in fused heterocycles via annulation (thiopyrano[2,3-d]thiazoles were found as cyclic isosteric mimetics of 5 -ene-4-thiazolidinones); iv) the leukaemia panel was detected to be the most sensitive among all cancer cell lines. The subsequent in silico and pharmacological data obtained in the investigation of the molecular mechanism of the anticancer effect revealed the apoptotic-related and mild prooxidant actions of the active compounds.
\end{abstract}

The main milestones of the project involved synthetic investigations, biological activity studies, rational approaches (QSAR-analysis, docking, molecular modelling etc.) to "drug-like" molecule design [1-3]. Initially, various activity types were studied (anti-inflammatory [4, 5], antimicrobial [6], anticonvulsant [7], choleretic [8], etc.), then investigations focussed on the study of anticancer, antimycobacterial, antiviral and antitrypanosomal activities. More than 2000 biological assays were conducted, allowing the identification of at least 200 hit compounds with anticancer action, 40 hits with antimycobacterial activity and 30 hits with the inhibitory activity against different virus strains. The early stage results demonstrated that the compounds possessed anti-inflam- matory activity, antimicrobial action, antioxidant, choleretic and anticonvulsant activities.

\section{Anticancer activity}

The in-house library of heterocycles has been an object for the study of anticancer activity within the $\mathrm{NCl}, \mathrm{NIH}$ protocol [9-11]. Among the 1,750 tested compounds, 525 (30.0\%) have successfully passed the pre-screening phase (Figure 2). After passing the second testing phase, 14 compounds were submitted for consideration by the $\mathrm{NCl}$ Biological Committee, among them, 8 compounds were affirmed for in-depth in vivo preclinical trials as potential anticancer agents. 


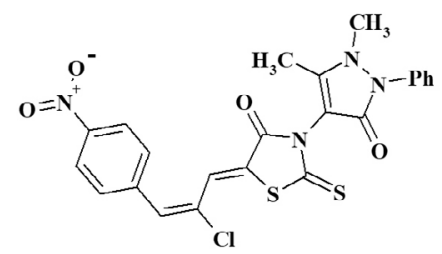

Anti-inflammatory activity
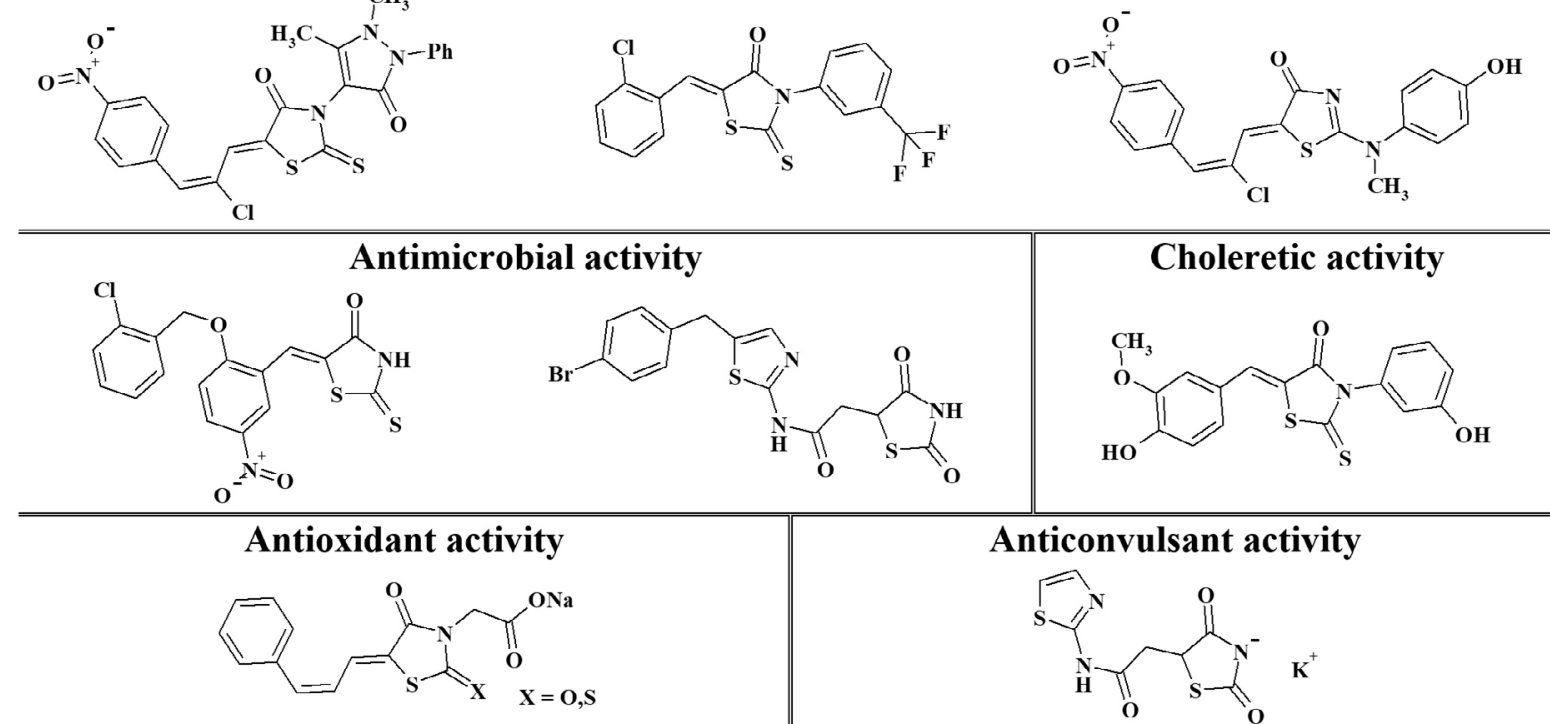

\section{Choleretic activity}

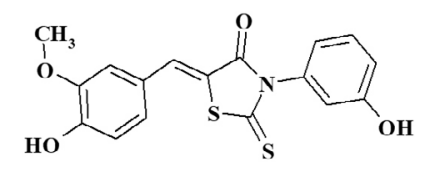

\section{Anticonvulsant activity}

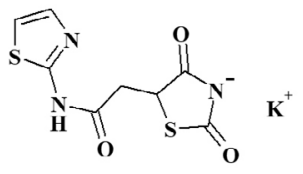

Figure 1. Hit compounds identified in the early stage of the project

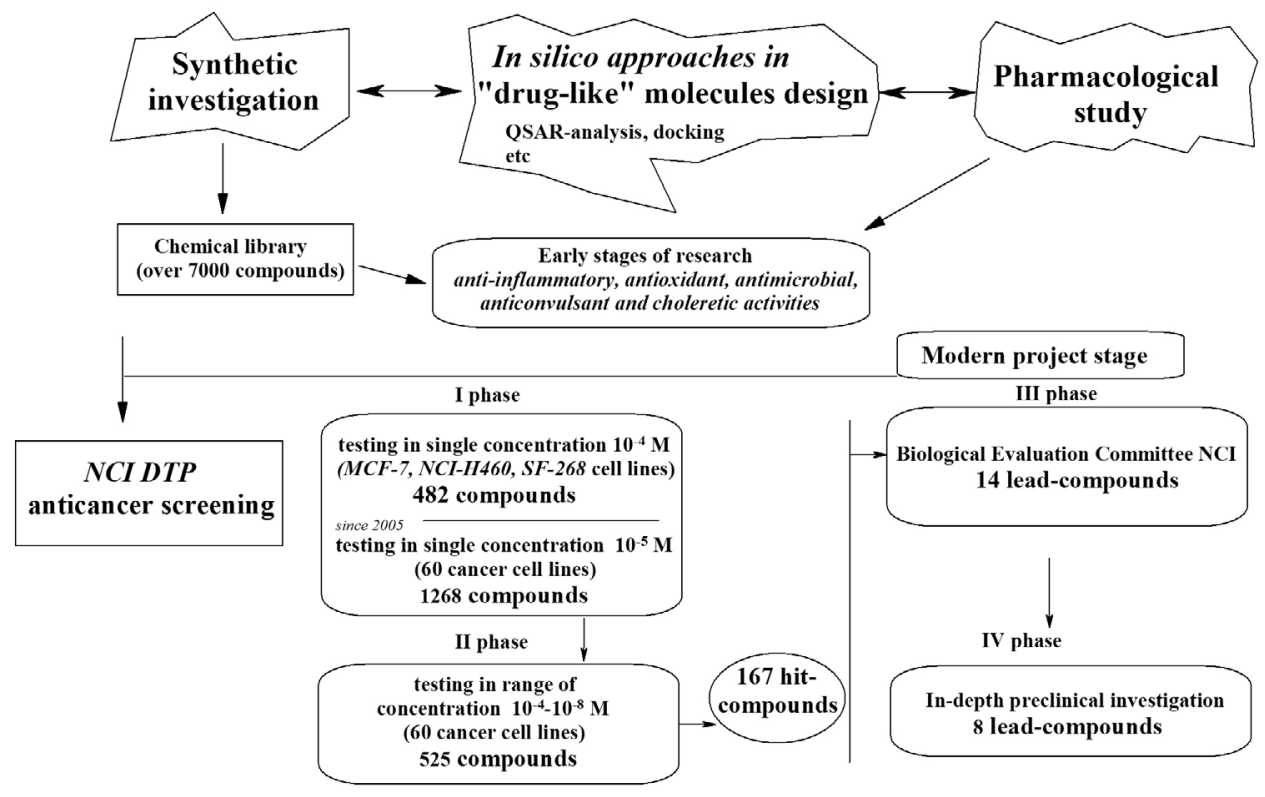

Figure 2. Scheme of the Department of Pharmaceutical, Organic and Bioorganic Chemistry project design

Figure 3 presents selected hit compounds from different groups that possess high antimitotic effect in vitro at submicromolar concentrations $\left(10^{-5}-10^{-8} \mathrm{M}\right)$ and are characterised by low in vivo toxicity. It is important to note that these compounds are representative of 5-ene-4 -thiazolidinones ("Biological way") [12-25] and thiopyrano[2,3-d]thiazoles ("Chemical way") [36-30].

Interestingly, in the anticancer selectivity rating, the leukaemia cell lines were the most sensitive to 4-thiazolidinones and related heterocyclic systems following the analysis of the in-depth in vitro research results. A series of cell lines, such as leukaemia lines (CCRF-CEM, HL-60(TB), RPMI8226, SR, K-562, MOLT-4), CNS cancer line (U251), non-small cell lung cancer line (HOP-92), renal cancer cell lines (UO-31, 786-O), colon cancer line (HCT-116) as well as breast cancer line (MDA$M B$ 231) were found to be the most sensitive to the test compounds. Thus, based on the obtained results, it was hypothesised that the heterocycles containing a "thiazolidinone matrix" have specific anti-leukaemia activity. 


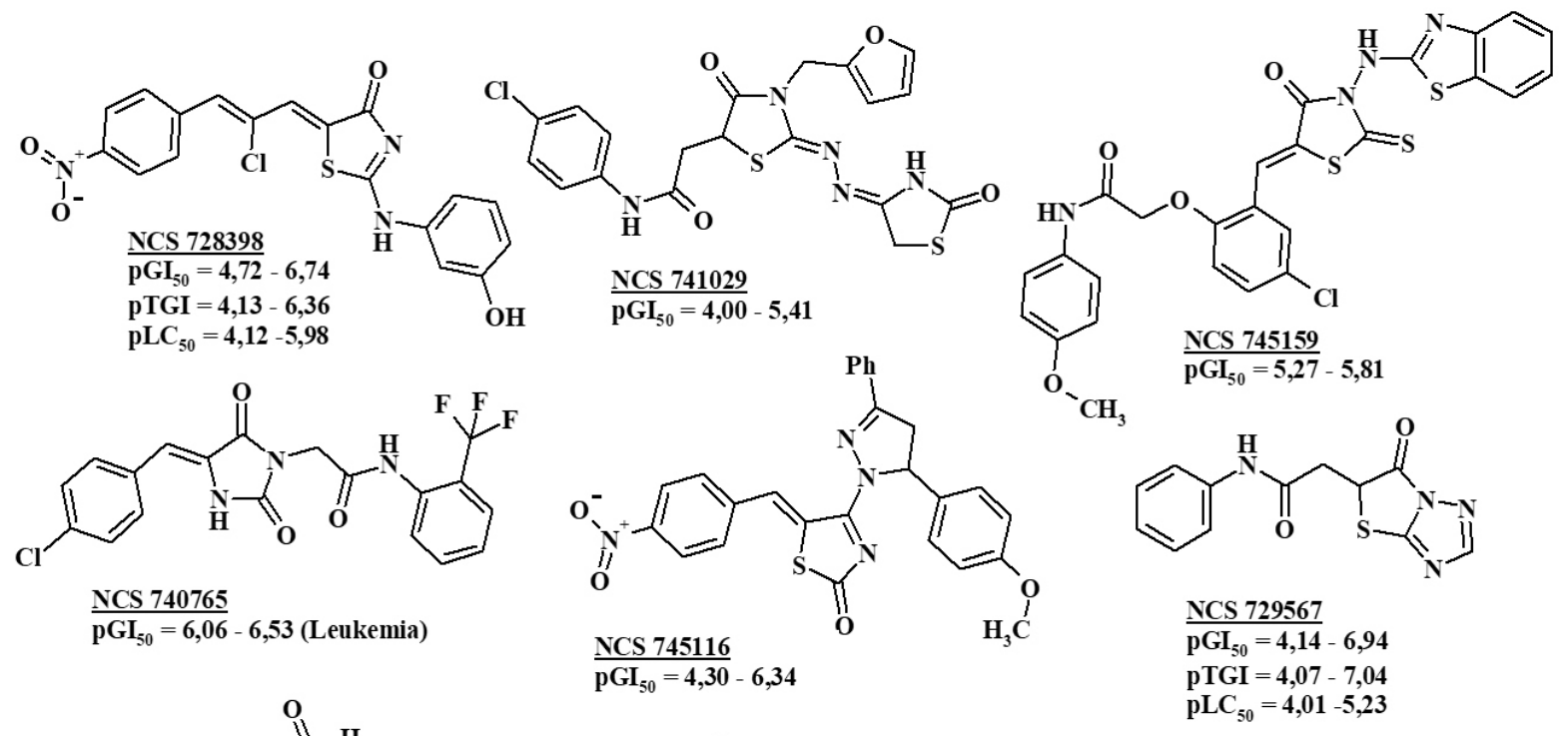

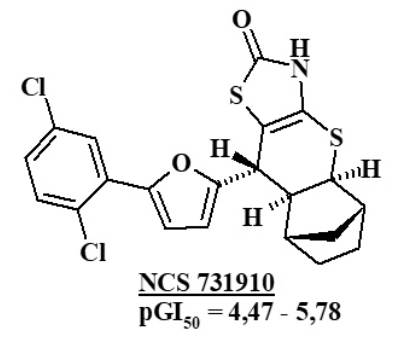

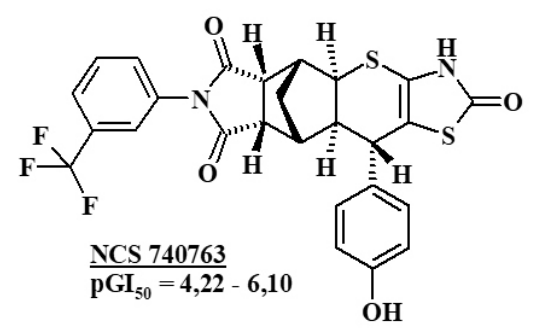<smiles>O=C(Cn1c2c(sc1=O)C1(CCSc3ccccc31)CO2)Nc1cccc(C(F)(F)F)c1</smiles><smiles>COc1ccc(/C=C2\SC(=O)N(CC(=O)Nc3ccc(C(=O)O)cc3)C2=O)cc1OC</smiles><smiles>O=C1N=C(N2C=C(c3ccccc3)CC2c2ccc(Cl)cc2)SC1=C1C(=O)Nc2ccccc21</smiles><smiles>O=CC1CSc2[nH]c(=O)sc2[C@H]1c1ccccc1</smiles>

NCS 745161 $\mathrm{pGI}_{50}=4,22-5,82$

Figure 3. Hit compounds from different groups of 4-thiazolidinone derivatives with a high antimitotic effect in vitro

In silico approaches for anticancer activity data analysis. The COMPARE analysis $[10,11]$ was performed for the active compounds to investigate the similarity of their cytotoxicity pattern (mean graph fingerprints) with those of known anticancer standard agents, $\mathrm{NCl}$ active synthetic compounds and natural products. For some synthesised heterocyclic substances, there was established correlation with the inhibitors of tubulin polymerisation, RNA polymerase, $\mathrm{p}$-glycoprotein or topoisomerase II, inductors of apoptosis and activators of caspases. It is of note that the significant values of the correlation coefficients of thiazolidinone derivatives from different sub-libraries to the S-trityl-L-cysteine, aminoa-
cyl-tRNA synthetases inhibitor with antiproliferative effect against leukaemia.

Following the analysis of anticancer activity profiles of different thiazolidinones using modern computational methods, like principal components analysis, neutral networks and cluster analysis, it was found that two different mechanisms and a "mixed" mechanism were responsible for the anticancer activity [3, 31-33].

In cooperation with the Institute of Cell Biology, NAS of Ukraine (Prof Rostyslav Stoika), the hypothesis regarding the apoptosis-dependent mechanism of antitumor activity was confirmed. Moreover, the proapoptotic activity of the tested compounds was observed. Studies have been 


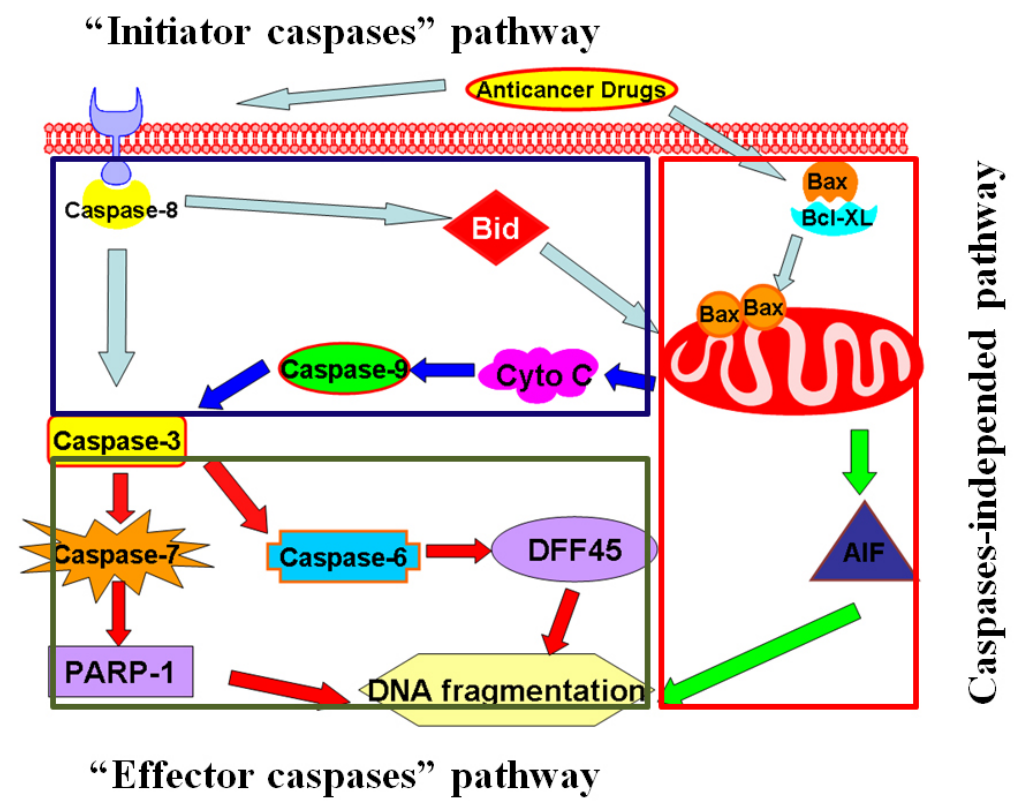

Figure 4. Plausible mechanisms of the anticancer effect of 5-ene-4-thiazolidinones

conducted regarding the effects of compounds on some cytokines, in particular, initiatory effector groups of caspases and cytokines involved in the development of caspase-independent apoptosis. Different apoptotic-related pathways were detected. Also, it should be noted that there were various implementations of such an effect, involving the "classic" apoptotic pathway (mediated by Bax \& Caspase-7), caspase-independent apoptosis (mediated by AIF) and "mixed-type" apoptosis (mediated by AIF, Bax \& Caspase-9) (Figure 4) [34-37]. This data correlated well with the results obtained in in silico studies [3, 31-33].
Based on the analysis of the biological and in silico data, we proposed a pharmacophore model for the design of potential anticancer agents [38, 39]. The pharmacophore (Figure 5) consists of two aromatic or $\pi$-ring system centres, a hydrophobic group and the two projections of the hydrogen bond donors (electron pair acceptors) (error rate $0.8 \%$, accuracy $87.5 \%$ and precision $=99.5 \%$ ).

A new sub-library was created (690 structures) by varying the substituents in the 2,4 and 5 positions of 4(2)-thiazolidinone. Pharmacophore and Random Forest models predicted 101 and 32 hit compounds from the virtual sub-li-

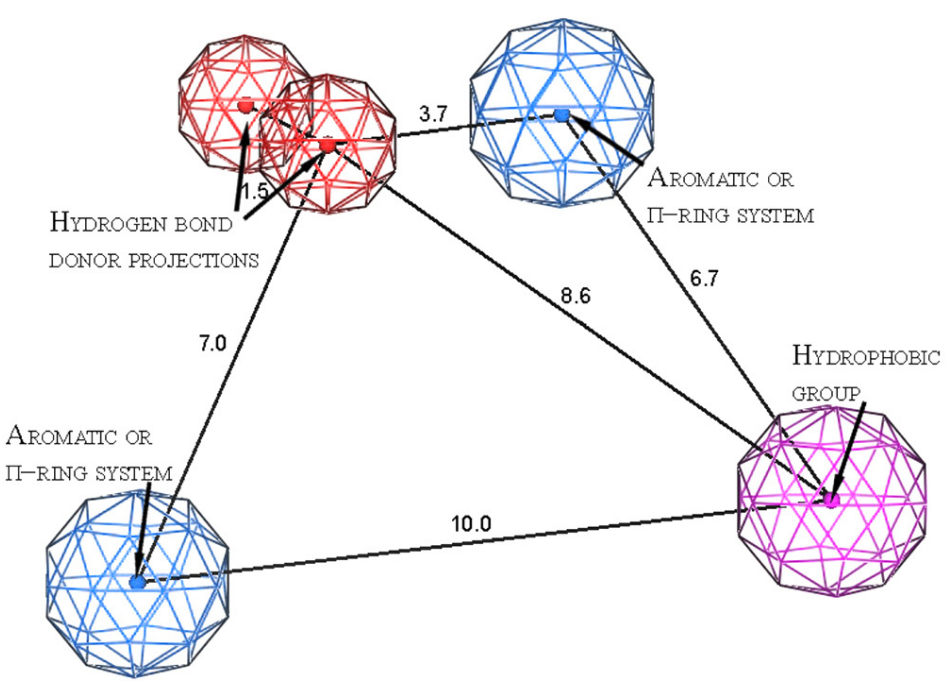

Figure 5. Probable pharmacophore model of 4-thiazolidinones anticancer activity 


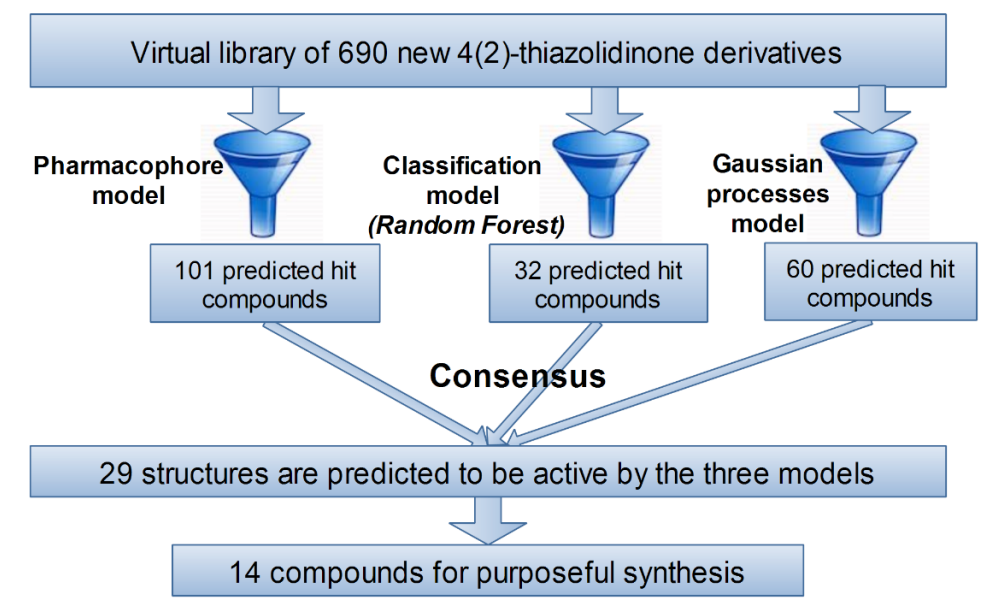

Figure 6. Virtual screening scheme

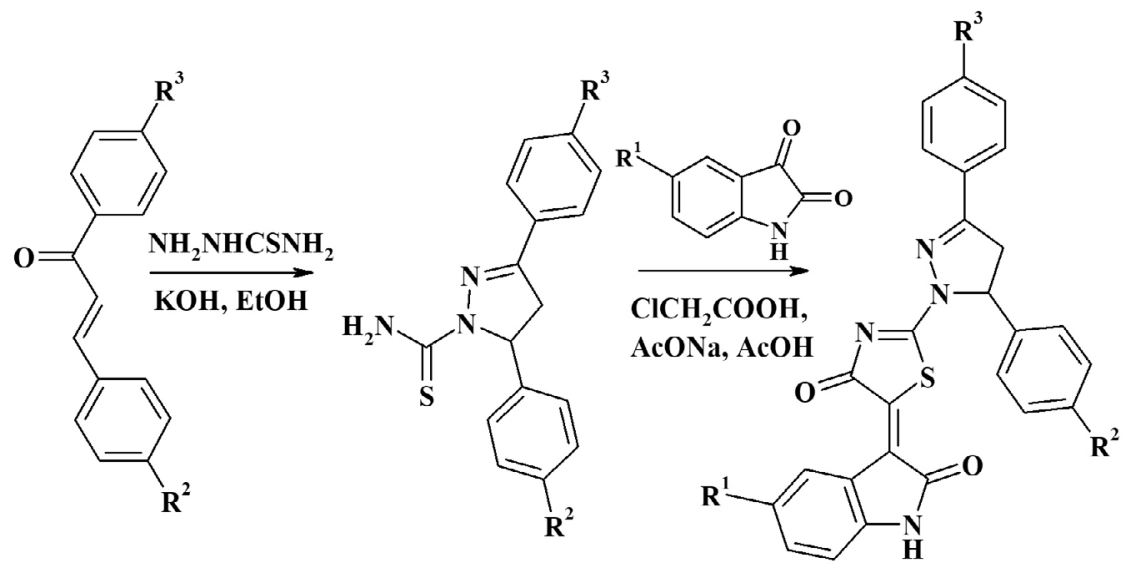

Scheme 1

92. $\mathrm{R}^{1}=\mathrm{H}, \mathrm{R}^{2}=\mathrm{R}^{3}=\mathrm{Cl}$,

93. $\mathrm{R}^{1}=\mathrm{R}^{2}=\mathrm{R}^{3}=\mathrm{Cl}$,

94. $\mathrm{R}^{\mathrm{l}}=\mathrm{Br}, \mathrm{R}^{2}=\mathrm{R}^{3}=\mathrm{Cl}$,

95. $\mathrm{R}^{1}=\mathrm{H}, \mathrm{R}^{2}=\mathrm{Cl}, \mathrm{R}^{3}=\mathrm{Br}$,

96. $\mathrm{R}^{1}=\mathrm{R}^{2}=\mathrm{Cl}, \mathrm{R}^{3}=\mathrm{Br}$,

97. $\mathrm{R}^{1}=\mathrm{R}^{3}=\mathrm{Br}, \mathrm{R}^{2}=\mathrm{Cl}$,

98. $\mathrm{R}^{1}=\mathrm{H}, \mathrm{R}^{2}=\mathrm{Cl}, \mathrm{R}^{3}=\mathrm{F}$,

99. $\mathrm{R}^{1}=\mathrm{R}^{2}=\mathrm{Cl}, \mathrm{R}^{3}=\mathrm{F}$,

100. $\mathrm{R}^{\mathrm{l}}=\mathrm{Br}, \mathrm{R}^{2}=\mathrm{Cl}, \mathrm{R}^{3}=\mathrm{F}$,

101. $\mathrm{R}^{1}=\mathrm{H}, \mathrm{R}^{2}=\mathrm{NMe}_{2}, \mathrm{R}^{3}=\mathrm{Cl}$,

102. $\mathrm{R}^{\mathrm{l}}=\mathrm{R}^{3}=\mathrm{Cl}, \mathrm{R}_{2}=\mathrm{NMe}_{2}$,

103. $\mathrm{R}^{1}=\mathrm{Br}, \mathrm{R}^{2}=\mathrm{NMe}_{2}, \mathrm{R}^{3}=\mathrm{Cl}$,

104. $R^{1}=H, R^{2}=\mathrm{NMc}_{2}, R^{3}=\mathrm{Br}$,

105. $\mathrm{R}^{1}=\mathrm{Cl}, \mathrm{R}^{2}=\mathrm{NMe}_{2}, \mathrm{R}^{3}=\mathrm{Br}$

brary, respectively. Analysis of the distances to the model showed that all predicted compounds were active, falling into the applicability domain, while 47 out-of-domain compounds were inactive. The Gaussian processes model predicted the cytotoxic effect on tumour cells for 60 structures. The choice of virtual screening hits was based on the consensus between all predictions, thereby predicting 29 hit compounds using these three screening models, of which, 14 structures were selected for synthesis (Figure 6).

Using the above-mentioned approach, 14 novel derivatives 92-105 were selected and synthesised (Scheme 1).

The success of the purposeful strategy was confirmed by biological assays, according to which, the synthesised compounds inhibited cancer cell growth, even at micromolar concentrations. The four most potent synthesised compounds 94, 96, 97 and 103 showed $I_{50}$ values between $0.16-10 \mu \mathrm{M}$ in MTT assays of rat glioma cells C6, Mino cells, Jurkat and L1210 cells.

\section{Antituberculosis activity}

The study of antimicrobial activity was conducted on the Mycobacterium tuberculosis H37Rv (ATCC 27294) within the Tuberculosis Antimicrobial Acquisition \& Coordination Facility (TAACF) Programme at the National Institute of Allergic and Infectious Diseases (NIAID, USA). Among the tested compounds, 40 active substances with an $\mathrm{IC}_{90}$ $\leq 10 \mu \mathrm{g} / \mathrm{mL}$ were identified, for which the cytotoxicity of mammalian cells $\left(\mathrm{CC}_{50}\right)$ was determined on VERO cells and a selectivity index $\left(\mathrm{SI}=\mathrm{CC}_{50}\right.$ / $\mathrm{IC}_{90}$ ) was calculated. For the in-depth studies, 7 derivatives (Figure 7) from different sub-libraries (5-ene-4-thiazolidinones and thiopyrano[2,3-d] thiazoles) were selected. 
<smiles>CCOC(=O)c1ccc(NC(=O)CCC(CC(=O)c2ccccc2)C(=O)O)cc1</smiles>

$\mathrm{IC}_{90}=0.989 \mu \mathrm{g} / \mathrm{mL}$ $\mathrm{CC}_{50}=16.558 \mu \mathrm{g} / \mathrm{mL}$ $\mathrm{SI}=18.438$

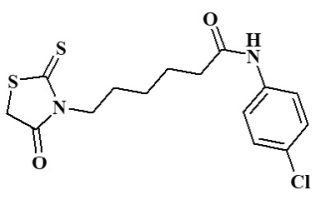

$\mathrm{IC}_{90}<0.195 \mu \mathrm{g} / \mathrm{mL}$ $\mathrm{CC}_{50}=5.034 \mu \mathrm{g} / \mathrm{mL}$ SI $>25.18$ $\mu \mathrm{g} / \mathrm{m}$ $\mathrm{SI}>49.14$

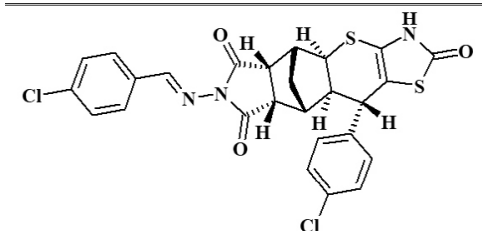

$\mathrm{IC}_{90}=0.424 \mu \mathrm{g} / \mathrm{mL}$ $\mathrm{CC}_{50}>40 \mu \mathrm{g} / \mathrm{mL}$ SI $>94.33$

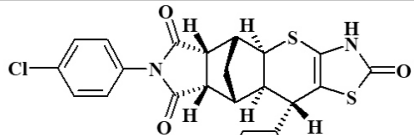
но

$\mathrm{IC}_{90}=9.4 \mu \mathrm{g} / \mathrm{mL}$ $\mathrm{CC}_{50}=34.264 \mu \mathrm{g} / \mathrm{mL}$ $\mathrm{SI}=3.645$

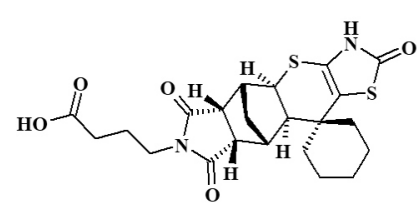

$\mathrm{IC}_{90}=0.852 \mu \mathrm{g} / \mathrm{mL}$ $\mathrm{CC}_{50}=13.547 \mu \mathrm{g} / \mathrm{mL}$ $\mathrm{SI}=15.9$

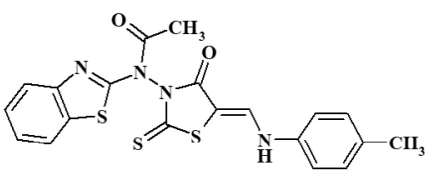

$\mathrm{IC}_{90}=0.870 \mu \mathrm{g} / \mathrm{mL}$ $\mathrm{CC}_{50}>40 \mu \mathrm{g} / \mathrm{mL}$ SI $>45.97$

Figure 7. Hit compounds with antituberculosis activity

\section{Hepatitis $B$ Virus $(\mathrm{HBV})$}

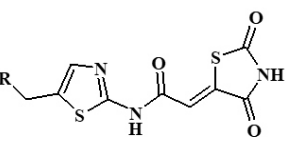

$\mathbf{R}=3-\mathbf{C F}_{3}-\mathbf{C}_{6} \mathbf{H}_{4}: \mathrm{EC}_{50}=3-11 \mu \mathrm{M}, \mathrm{EC}_{90}=9-29 \mu \mathrm{M}, \mathrm{SI}>10-33$

$\mathbf{R}=$ 1-Naphtyl: $\mathrm{EC}_{50}=5-14 \mu \mathrm{M}, \mathrm{EC}_{90}=13-35 \mu \mathrm{M}, \mathrm{SI}>8.6-23$

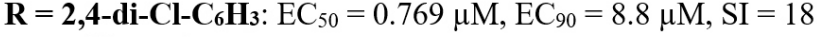

Hepatitis C Virus (HCV)

$\mathbf{R}=\mathbf{3}-\mathbf{C F}_{3}-\mathbf{C}_{6} \mathbf{H}_{4}:$ : Inh. virus $=93.1 \%$, cytotoxicity $=23.8 \%$

$\mathbf{R}=$ 1-Naphtyl: $\%$ Inh. virus $=92.2 \%$, cytotoxicity $=37.1 \%$

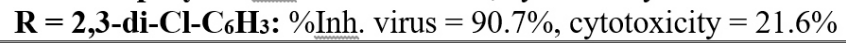

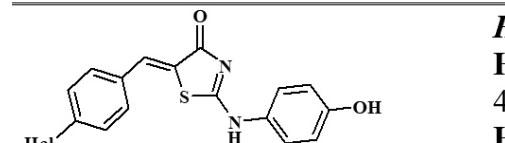

Herpes viruses

$\mathbf{H a l}=\mathbf{F}: \mathrm{EC}_{50}=1.4 \mu \mathrm{M}, \mathrm{EC}_{90}>12 \mu \mathrm{M}, \mathrm{CC}_{50}=55.6 \mu \mathrm{M}, \mathrm{SI}=$ 40

Hal $=$ Cl: $\mathrm{EC}_{50}=8 \mu \mathrm{M}, \mathrm{EC}_{90}=12 \mu \mathrm{M}, \mathrm{CC}_{50}>300 \mu \mathrm{M}, \mathrm{SI}>37.5$

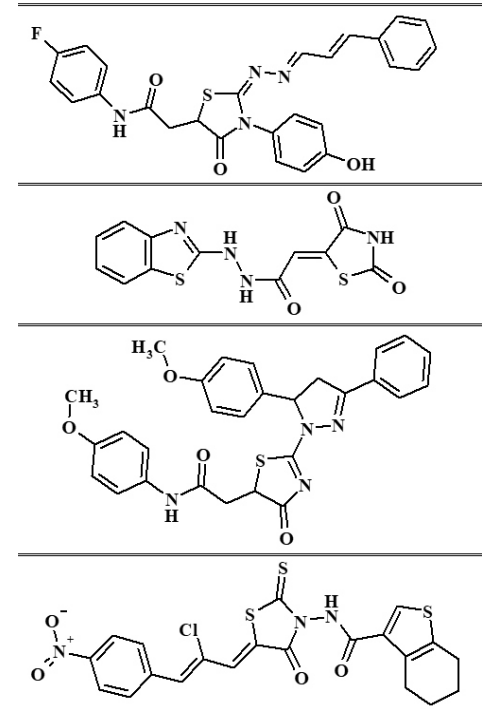

Flu $A$ Virus (Duck)

$\mathrm{EC}_{50}=2.8-3.7 \mu \mathrm{M}, \mathrm{EC}_{90}=39 \mu \mathrm{M}, \mathrm{SI}>2.6-36$

SARS

$\mathrm{EC}_{50}=9.6 \mu \mathrm{M}, \mathrm{CC}_{50}=34 \mu \mathrm{M}, \mathrm{SI}>3.5$

Virus Tacaribe (biological weapons virus)

$\mathrm{EC}_{50}=0.71-1.5 \mu \mathrm{M}, \mathrm{IC}_{50}=28-89 \mu \mathrm{M}, \mathrm{SI}=19-130$

\section{Cytomegalovirus}

$\mathrm{EC}_{50}=1.1 \mu \mathrm{M}, \mathrm{EC}_{90}>2.4 \mu \mathrm{M}, \mathrm{CC}_{50}=8.9 \mu \mathrm{M}, \mathrm{SI}=8.1$

Figure 8. Hit compounds with antiviral activity 


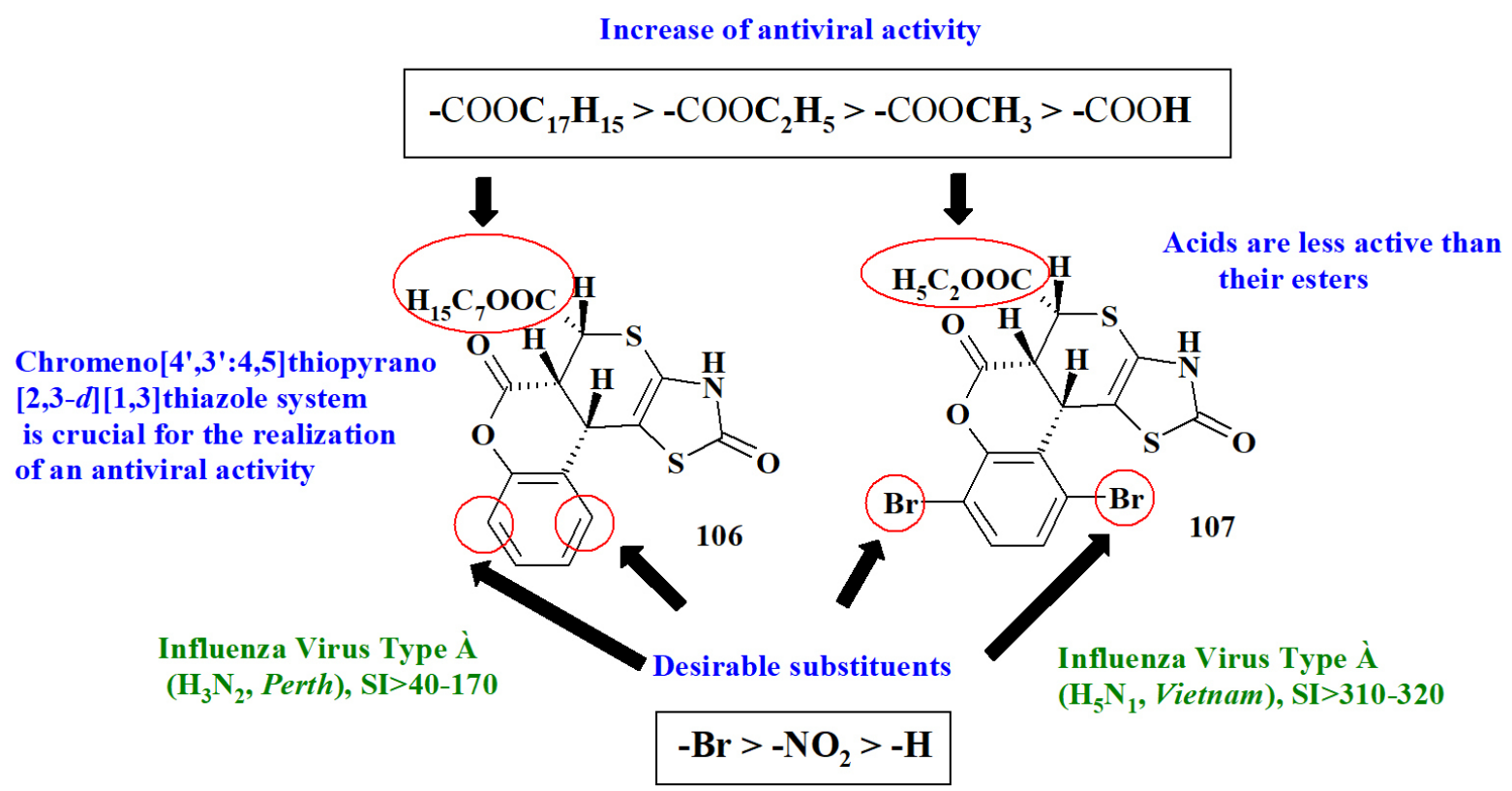

THE MOST ACTIVE COMPOUNDS

Figure 9. SAR study of thiopyrano[2,3- $d][1,3]$ thiazoles

Thiopyrano[2,3-d]thiazoles<smiles></smiles>

$\mathbf{R}=\mathbf{3 , 4}-(\mathrm{OMe}) \mathbf{2}$

$\mathrm{IC}_{50}=0.26 \mu \mathrm{M}(T B B), 0.42 \mu \mathrm{M}(T B G)$

$\mathbf{R}=\mathbf{4}-\mathbf{N M e}_{2}$

$\mathrm{IC}_{50}=1.26 \mu \mathrm{M}(T B B), 1.46 \mu \mathrm{M}(T B G)$

$\mathbf{R}=\mathbf{4}-\mathbf{N E t}_{2}$

$\mathrm{IC}_{50}=2.39 \mu \mathrm{M}(T B B), 0.93 \mu \mathrm{M}(T B G)$

4-Thiazolidinone-hydrazones<smiles>CCC1S/C(=C\N=Cc2c(-c3ccccc3)[nH]c3ccccc23)NC1=O</smiles>

$\mathrm{IC}_{50}=0.03 \mu \mathrm{M}(T B B), 0.11 \mu \mathrm{M}(T B G)$

Pyrazoline-thiazolidine conjugates

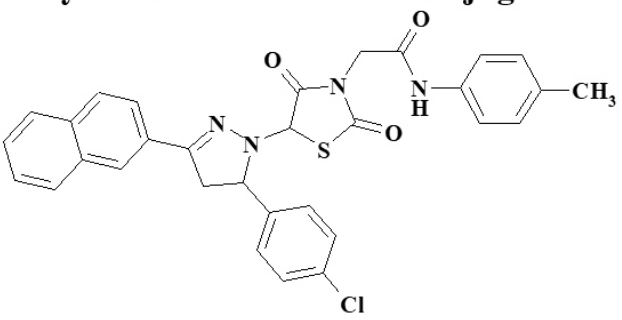

$\mathrm{IC}_{50}=2.53 \mu \mathrm{M}(T B B), 5.43 \mu \mathrm{M}(T B G)$
5-Enamine-4-thiazolidinones<smiles>CCOC(=O)c1ccc(N/C=C2\SC(=S)N(C(Cc3ccccc3)C(=O)OCC)C2=O)cc1</smiles>

$\mathrm{IC}_{50}=0.091 \mu \mathrm{M}(T B B), 0.027 \mu \mathrm{M}(T B G)$

Figure 10. Hit compounds with pronounced antitrypanosomal activity

2-Hetarylimino-4-thiazolidinones<smiles>[SiH3]</smiles><smiles>Cc1ccc(/C=C2\S/C(=N/c3nccs3)SC2=O)cc1</smiles>

$\mathrm{IC}_{50}=1.09 \mu \mathrm{M}(T B B), 1.09 \mu \mathrm{M}(T B G)$

The pyrazoline-isatin conjugates

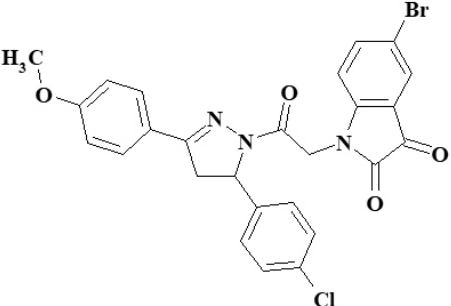

$\mathrm{IC}_{50}=1.49 \mu \mathrm{M}(T B B), 0.76 \mu \mathrm{M}(T B G)$ 


\section{Antiviral activity}

Screening of the antiviral activity of the synthesised compounds was also conducted within the Antimicrobial Acquisition \& Coordination Facility (AACF, NIAID, USA) Programme. As a result, 30 compounds were identified with significant antiviral activity and sufficient selectivity indices [26, 40-43]. In addition, a group of 4-thiazolidinone-related compounds (Figure 8) with a strong effect on hepatitis B (HBV) and C (NSV) and Flu A \& B viruses were identified, as well as one high-level SARS and Tacaribe strain (biological weapons virus).

Derivatives of rel-(5R,5aR,11bS)-2,6-dioxo$3,5 a, 6,11 b$-tetrahydro- $2 \mathrm{H}, 5 \mathrm{H}$-chromeno[4',3':4,5] thiopyrano[2,3- $d][1,3]$ thiazole-5-carboxylic acids belong to the most promising group of compounds (Figure 9). The substituents in the positions 8 and 10 and the ester group in position 5 are desirable for antiviral activity. The increase of the alkyl moiety length leads to an increased effect, thus, compound 106 showed a higher activity against Influenza Virus Type $A\left(\mathrm{H}_{3} \mathrm{~N}_{2}\right.$, Perth strain) with an $\mathrm{EC}_{50}=0.6 \div 2.5 \mu \mathrm{g} / \mathrm{ml}$ and $\mathrm{SI}=40 \div 170$ than derivative 107 with an $\mathrm{EC}_{50}=$ $0.31 \div 0.32 \mu \mathrm{g} / \mathrm{ml}$ and $\mathrm{SI}=>310 \div 320$ [42].

The study of antitrypanosomal activity was conducted at the National Museum of Natural History (Prof Philippe Grellier, France) on Trypanosoma brucei brucei (TBB) and Trypanosoma brucei gambiense (TBG) strains. Among more than 200 tested compounds, a series of hits with pronounced antiparasitic activity in cellulo with $\mathrm{IC}_{50}$ values of $0.03-15.64 \mu \mathrm{g} / \mathrm{ml}$ were identified (Figure 10) [27, 43-48].

\section{Conclusions and fur- ther perspectives}

, 4-Thiazolidinones possess a variety of biological activities, both in screening campaigns and directed experiments, hence are considered as a tool for the synthesis of related heterocycles, simplified analogues and diversity complex heterocycles within various approaches.

2 Among the variety of thiazolidinone subtypes, 5 -ene-thiazolidinones are of special interest as hit- and lead-compounds possessing anticancer, antimicrobial, antiviral, and antitrypanosomal activities.
, Assigning 5-ene-thiazolidinones as pan assay interference compounds (PAINS) due to their possible Michael acceptor functionality must be analysed in-depth: experimental confirmation is essential to claim target compounds as PAINS; the positive aspect of such covalent modifiers should not be discarded.

, Annealing of a thiazolidine core into thiopyranothiazole analogues is one of prominent optimisation directions which will allow conservation of the activity pattern of synthetic precursors (5-ene-4-thiazolidinones), decrease the toxicity and avoid the Michael acceptor properties.

, The main directions for 4-thiazolidinones optimisation are: i) complication of the fragment in the C5 position; ii) introduction of the substituents in the N3 position (especially fragments with carboxylic group or its derivatives); iii) annealing in complex heterocyclic systems; iv) combination with other pharmacologically attractive fragments within a hybrid pharmacophore approach.

, 4-Thiazolidinones are useful tools for medicinal chemistry and should not be regarded as useless per se.

\section{Acknowledgements}

\section{Conflict of interest statement}

The authors declare no conflict of interest.

\section{Funding sources}

There are no sources of funding to declare.

\section{References}

1. Lesyk RB, Zimenkovsky BS, Kaminskyy DV, Kryshchyshyn AP, Havryluk DY, Atamanyuk DV, Subtel'na IY, Khyluk DV. Thiazolidinone motif in anticancer drug discovery. Experience of DH LNMU medicinal chemistry scientific group. Biopolymers and Cell. 2011 Mar 20;27(2):107-117. https://doi.org/10.7124/ bc.000089

2. Devinyak O, Zimenkovsky B, Lesyk R. Biologically Active 4-Thiazolidinones: A Review of QSAR Studies and QSAR Modeling of Antitumor Activity. Current Topics in Medicinal Chemistry. 2013 Mar 1;12(24):2763-2784. https://doi. org/10.2174/1568026611212240006

3. Devinyak O, Havrylyuk D, Zimenkovsky B, Lesyk R. Computational Search for Possible Mechanisms of 4-Thiazolidinones Anticancer Activity: The Power of Visualization. Molecular Informatics. 2014 Mar;33(3):216-229. https://doi.org/10.1002/ minf. 201300086 
4. Lesyk R, Vladzimirska O, Zimenkovsky B, Golota S, Nektgayev I, Cherpak O, Leb'yak M, Kozak O. Synthesis and antiinflammatory activity of novel 3-(2,3dimethyl-1-phenyl-4-pyrazolon-5-yl)-4-thiazolidones. Boll Chim Farm. 2002 May-Jun;141(3):197201. PMID 12197418

5. Lesyk R, Vladzimirska O, Zimenkovsky B, Horishny $\mathrm{V}$, Nektegayev I, Solyanyk V, Vovk O. New thiazolidones- 4 with pyrazolone- 5 substituent as the potential NSAIDs. Boll Chim Farm. 1998 Jun;137(6):210-7. PMID 9713155

6. Zimenkovskii BS, Kutsyk RV, Lesyk RB, Matyichuk VS, Obushak ND, Klyufinska TI. Synthesis and antimicrobial activity of 2,4-dioxothiazolidine-5-acetic acid amides. Pharmaceutical Chemistry Journal. 2006 Jun;40(6):303-306. https://doi.org/10.1007/s11094006-0115-6

7. Lesyk R, Pinyazhko O, Myronenko S, Nektegayev I. 5-(3-Nitrobenzylidene)-2-(thiazol-2-ylimino)-4-thiazolidinone exhibiting anticonvulsant effect. Disclosure 12.10.2015.. 2016 Mar 10; UA 105330 (Ukraine).

8. Nektegayev I, Lesyk R. ChemInform Abstract: 3-Oxyaryl-2-thionethiazolidones- 4 and Their Choleretic Activity. Scientia Pharmaceutica. 2010 Mar;67(10):227-30. https://doi.org/10.1002/chin.200010126

9. Boyd MR, Paull KD. Some practical considerations and applications of the national cancer institute in vitro anticancer drug discovery screen. Drug Development Research. 1995 Feb;34(2):91-109. https:// doi.org/10.1002/ddr.430340203

10. Shoemaker RH. The NCI60 human tumour cell line anticancer drug screen. Nature Reviews Cancer. 2006 Oct;6(10):813-823. https://doi.org/10.1038/nrc1951

11. Paull KD, Shoemaker RH, Hodes L, Monks A, Scudiero DA, Rubinstein L, Plowman J, Boyd MR. Display and Analysis of Patterns of Differential Activity of Drugs Against Human Tumor Cell Lines: Development of Mean Graph and COMPARE Algorithm. JNCI Journal of the National Cancer Institute. 1989 Jul 19;81(14):10881092. https://doi.org/10.1093/jnci/81.14.1088

12. Havrylyuk D, Mosula L, Zimenkovsky B, Vasylenko 0 , Gzella A, Lesyk R. Synthesis and anticancer activity evaluation of 4-thiazolidinones containing benzothiazole moiety. European Journal of Medicinal Chemistry. 2010 Nov;45(11):5012-5021. https://doi. org/10.1016/j.ejmech.2010.08.008

13. Kaminskyy D, den Hartog GJ, Wojtyra M, Lelyukh M, Gzella A, Bast A, Lesyk R. Antifibrotic and anticancer action of 5-ene amino/iminothiazolidinones. European Journal of Medicinal Chemistry. 2016 Apr;112:180195. https://doi.org/10.1016/j.ejmech.2016.02.011

14. Senkiv J, Finiuk N, Kaminskyy D, Havrylyuk D, Wojtyra M, Kril I, Gzella A, Stoika R, Lesyk R. 5-Ene-4-thiazolidinones induce apoptosis in mammalian leukemia cells. European Journal of Medicinal Chemistry. 2016 Jul;117:33-46. https://doi.org/10.1016/j. ejmech.2016.03.089

15. Kaminskyy D, Khyluk D, Vasylenko O, Zaprutko L, Lesyk R. A Facile Synthesis and Anticancer Activity Evaluation of Spiro[Thiazolidinone-Isatin] Conjugates. Scientia Pharmaceutica. 2011;79(4):763-777. https://doi.org/10.3797/scipharm.1109-14
16. Havrylyuk D, Zimenkovsky B, Vasylenko O, Gzella A, Lesyk R. Synthesis of New 4-Thiazolidinone-, Pyrazoline-, and Isatin-Based Conjugates with Promising Antitumor Activity. Journal of Medicinal Chemistry. 2012 Oct 9;55(20):8630-8641. https://doi.org/10.1021/jm300789g

17. Kaminskyy D, Zimenkovsky B, Lesyk R. Synthesis and in vitro anticancer activity of 2,4-azolidinedioneacetic acids derivatives. European Journal of Medicinal Chemistry. 2009 Sep;44(9):3627-3636. https:// doi.org/10.1016/j.ejmech.2009.02.023

18. Havrylyuk D, Zimenkovsky B, Lesyk R. Synthesis and Anticancer Activity of Novel Nonfused Bicyclic Thiazolidinone Derivatives. Phosphorus, Sulfur, and Silicon and the Related Elements. 2009 Mar 10;184(3):638650. https://doi.org/10.1080/10426500802247563

19. Subtel'na I, Atamanyuk D, Szymańska E, KiećKononowicz K, Zimenkovsky B, Vasylenko O, Gzella A, Lesyk R. Synthesis of 5-arylidene-2-amino-4-azolones and evaluation of their anticancer activity. Bioorganic \& Medicinal Chemistry. 2010 Jul;18(14):50905102. https://doi.org/10.1016/j.bmc.2010.05.073

20. Havrylyuk D, Kovach N, Zimenkovsky B, Vasylenko O, Lesyk R. Synthesis and Anticancer Activity of Isatin-Based Pyrazolines and Thiazolidines Conjugates. Archiv der Pharmazie. 2011 Jun 16;344(8):514-522. https://doi.org/10.1002/ardp.201100055

21. Avdieiev S, Gera L, Havrylyuk D, Hodges RS, Lesyk R, Ribrag V, Vassetzky Y, Kavsan V. Bradykinin antagonists and thiazolidinone derivatives as new potential anti-cancer compounds. Bioorganic \& Medicinal Chemistry. 2014 Aug;22(15):3815-3823. https://doi. org/10.1016/j.bmc.2014.06.046

22. Kaminskyy D, Subtel'na I, Zimenkovsky B, Karpenko O, Gzella A, Lesyk R. Synthesis and Evaluation of Anticancer Activity of 5-Ylidene-4- Aminothiazol-2(5H)-one Derivatives. Medicinal Chemistry. $2015 \mathrm{Jul}$ 24;11(6):517-530. https://doi.org/10.2174/157340641 1666150211112049

23. Szychowski KA, Leja ML, Kaminskyy DV, Binduga UE, Pinyazhko OR, Lesyk RB, Gmiński J. Study of novel anticancer 4-thiazolidinone derivatives. ChemicoBiological Interactions. 2017 Jan;262:46-56. https:// doi.org/10.1016/j.cbi.2016.12.008

24. Szychowski KA, Leja ML, Kaminskyy DV, Kryshchyshyn AP, Binduga UE, Pinyazhko OR, Lesyk RB, Tobiasz J, Gmiński J. Anticancer properties of 4-thiazolidinone derivatives depend on peroxisome proliferator-activated receptor gamma (PPARy). European Journal of Medicinal Chemistry. 2017 Dec;141:162168. https://doi.org/10.1016/j.ejmech.2017.09.071

25. Szychowski KA, Kaminskyy DV, Leja ML, Kryshchyshyn AP, Lesyk RB, Tobiasz J, Wnuk M, Pomianek T, Gmiński J. Anticancer properties of 5Z-(4fluorobenzylidene)-2-(4-hydroxyphenylamino)-thiazol-4-one. Scientific Reports. 2019 Jul 23;9(1). https://doi.org/10.1038/s41598-019-47177-6

26. Lozynskyi A, Golota S, Zimenkovsky B, Atamanyuk D, Gzella A, Lesyk R. Synthesis, anticancer and antiviral activities of novel thiopyrano[2,3-d]thiazole-6carbaldehydes. Phosphorus, Sulfur, and Silicon and the Related Elements. 2016 Mar 30;191(9):1245-1249. https://doi.org/10.1080/10426507.2016.1166108 
27. Kryshchyshyn AP, Atamanyuk DV, Kaminskyy DV, Grellier P, Lesyk RB. Investigation of anticancer and antiparasitic activity of thiopyrano[2,3-d]thiazoles bearing norbornane moiety. Biopolymers and Cell. 2017 Jun 30;33(3):183-205. https://doi.org/10.7124/bc.00094f

28. Atamanyuk D, Zimenkovsky B, Lesyk R. Synthesis and anticancer activity of novel thiopyrano[2,3-d]thiazole-based compounds containing norbornane moiety. Journal of Sulfur Chemistry. 2008 Apr;29(2):151162. https://doi.org/10.1080/17415990801911723

29. Atamanyuk D. Synthesis and Biological Activity of New Thiopyrano[2,3-d]thiazoles Containing a Naphthoquinone Moiety. Scientia Pharmaceutica. 2013;81(2):423-436. https://doi.org/10.3797/ scipharm.1301-13

30. Zelisko NI, Finiuk NS, Shvets VM, Medvid YO, Stoika RS, Lesyk RB. Screening of spiro-substituted thiopyrano[2,3-d]thiazoles for their cytotoxic action on tumor cells. Biopolymers and Cell. 2017 Aug 31;33(4):282-290. https://doi.org/10.7124/bc.00095a

31. Zimenkovsky B, Devinyak O, Havrylyuk D, Lesyk R. Analysis of antitumor activity of 4-thiazolidinone derivatives and their classification by probable mechanisms of action using mathematical statistics. Journal of Organic and Pharmaceutical Chemistry. 2011;9(3):64-71.

32. Zimenkovsky B, Devinyak O, Lesyk R. The study of the "structure - anticancer activity" relationship of 4-thiazolidinones using regression analysis and classification modeling. Journal of Organic and Pharmaceutical Chemistry. 2012;2:43-9.

33. Devinyak O, Lesyk R. Investigation of the relationship between the structure of 4-thiazolidinones and their antitumor activity by multidimensional adaptive regression splines. Journal of Organic and Pharmaceutical Chemistry. 2013;11(3):62-7.

34. Senkiv J, Finiuk N, Kaminskyy D, Havrylyuk D, Wojtyra M, Kril I, Gzella A, Stoika R, Lesyk R. 5-Ene-4-thiazolidinones induce apoptosis in mammalian leukemia cells. European Journal of Medicinal Chemistry. 2016 Jul;117:33-46. https://doi.org/10.1016/j. ejmech.2016.03.089

35. Chumak V, Fil M, Panchuk R, Zimenkovsky B, Havrylyuk D, Lesyk R, Stoika R. Study of antineoplastic action of novel isomeric derivatives of 4-thiazolidinone. Ukrainskiĭ biokhimicheskiĭ zhurnal. 2014;86:96-105.

36. Kobylinska LI, Boiko NM, Panchuk RR, Grytsyna II, Klyuchivska OY, Biletska LP, Lesyk RB, Zimenkovsky BS, Stoika RS. Putative anticancer potential of novel 4-thiazolidinone derivatives: cytotoxicity toward rat C6 glioma in vitro and correlation of general toxicity with the balance of free radical oxidation in rats. Croatian Medical Journal. 2016 Apr;57(2):151-163. https://doi.org/10.3325/cmj.2016.57.151

37. Havrylyuk D, Zimenkovsky B, Lesyk R, Stoika R, Lutsyk M, Panchuk R. 5-[2-Chloro-3-(4-nitrophenyl)allylidene]-4-(3,5-diaryl-4,5-dihydropyrazol-1-yl)-5$\mathrm{H}$-thiazol-2-ones exhibiting antitumor activity in vitro and in vivo, and their solubilization method. Disclosure 21.08.2013. 2015 Jul 27; UA 109177 (Ukraine).
38. Zimenkovsky B, Devinyak O, Lesyk R. Modeling of a possible pharmacophore group for 4-thiazolidinones with the anticancer activity (Моделювання можливої фармакофорної групи 4-тіазолідинонів зпротипухлинноюактивністю). Журналорганічної та фармацевтичної хімії. 2012;10:76-82.

39. Zimenkovsky BS, Lesyk RB, Devinyak OT, Havrylyuk DY. Method for antitumor activity predicting of 4-thiazolidinone derivatives. Disclosure 18.12.2012. 2013 May 27; UA 80435 (Ukraine).

40. Ouyang G, Cai X, Chen Z, Song B, Bhadury PS, Yang $S$, Jin L, Xue W, Hu D, Zeng S. Synthesis and Antiviral Activities of Pyrazole Derivatives Containing an Oxime Moiety. Journal of Agricultural and Food Chemistry. 2008 Nov 12;56(21):10160-10167. https://doi. org/10.1021/jf802489e

41. Havrylyuk D, Zimenkovsky B, Vasylenko O, Lesyk R. Synthesis and Anticancer and Antiviral Activities of New 2-Pyrazoline-Substituted 4-Thiazolidinones. Journal of Heterocyclic Chemistry. 2013 Feb;50(S1):E55-E62. https://doi.org/10.1002/jhet.1056

42. Zelisko NI, Demchuk I, Lesyk R. New thiopyrano[2,3-d] $[1,3]$ thiazole derivatives as potential antiviral agents. The Ukrainian Biochemical Journal. 2016 Jun 30;88(Special Issue):105-112. https://doi. org/10.15407/ubj88.si01.105

43. Havrylyuk D, Zimenkovsky B, Vasylenko O, Day CW, Smee DF, Grellier P, Lesyk R. Synthesis and biological activity evaluation of 5 -pyrazoline substituted 4 -thiazolidinones. European Journal of Medicinal Chemistry. 2013 Aug;66:228-237. https://doi.org/10.1016/j. ejmech.2013.05.044

44. Wojtyra MN, Lesyk RB, Zimenkovsky BS, Grellier P. (Z)-(5-[5-(3,5-diaryl-4,5-dihydropyrazol-1-ylmethylidene)-3-(pyridine-3-yl)-2-thioxothiazolidin4-ones exhibiting antitrypanosomal action. Disclosure 18.04.2017. 2017 Oct 10; UA 119822 (Ukraine).

45. Holota S, Kryshchyshyn A, Derkach H, Trufin $Y$, Demchuk I, Gzella A, Grellier P, Lesyk R. Synthesis of 5-enamine-4-thiazolidinone derivatives with trypanocidal and anticancer activity. Bioorganic Chemistry. 2019 May;86:126-136. https://doi. org/10.1016/j.bioorg.2019.01.045

46. Kryshchyshyn A, Kaminskyy D, Karpenko O, Gzella A, Grellier P, Lesyk R. Thiazolidinone/thiazole based hybrids - New class of antitrypanosomal agents. European Journal of Medicinal Chemistry. 2019 Jul;174:292308. https://doi.org/10.1016/j.ejmech.2019.04.052

47. Zelisko N, Karpenko O, Muzychenko V, Gzella A, Grellier P, Lesyk R. trans -Aconitic acid-based hetero -Diels-Alder reaction in the synthesis of thiopyrano[2,3- $d][1,3]$ thiazole derivatives. Tetrahedron Letters. 2017 May;58(18):1751-1754. https://doi. org/10.1016/j.tetlet.2017.03.062

48. Zelisko N, Atamanyuk D, Vasylenko O, Grellier P, Lesyk $R$. Synthesis and antitrypanosomal activity of new 6,6,7-trisubstituted thiopyrano[2,3-d][1,3]thiazoles. Bioorganic \& Medicinal Chemistry Letters. 2012 Dec;22(23):7071-7074. https://doi.org/10.1016/j. bmcl.2012.09.091 